\title{
Optical Performance of the TBC-2 Solar Collector Before and After the 1993 Mirror Lustering
}

Richard M. Houser and John W. Strachan

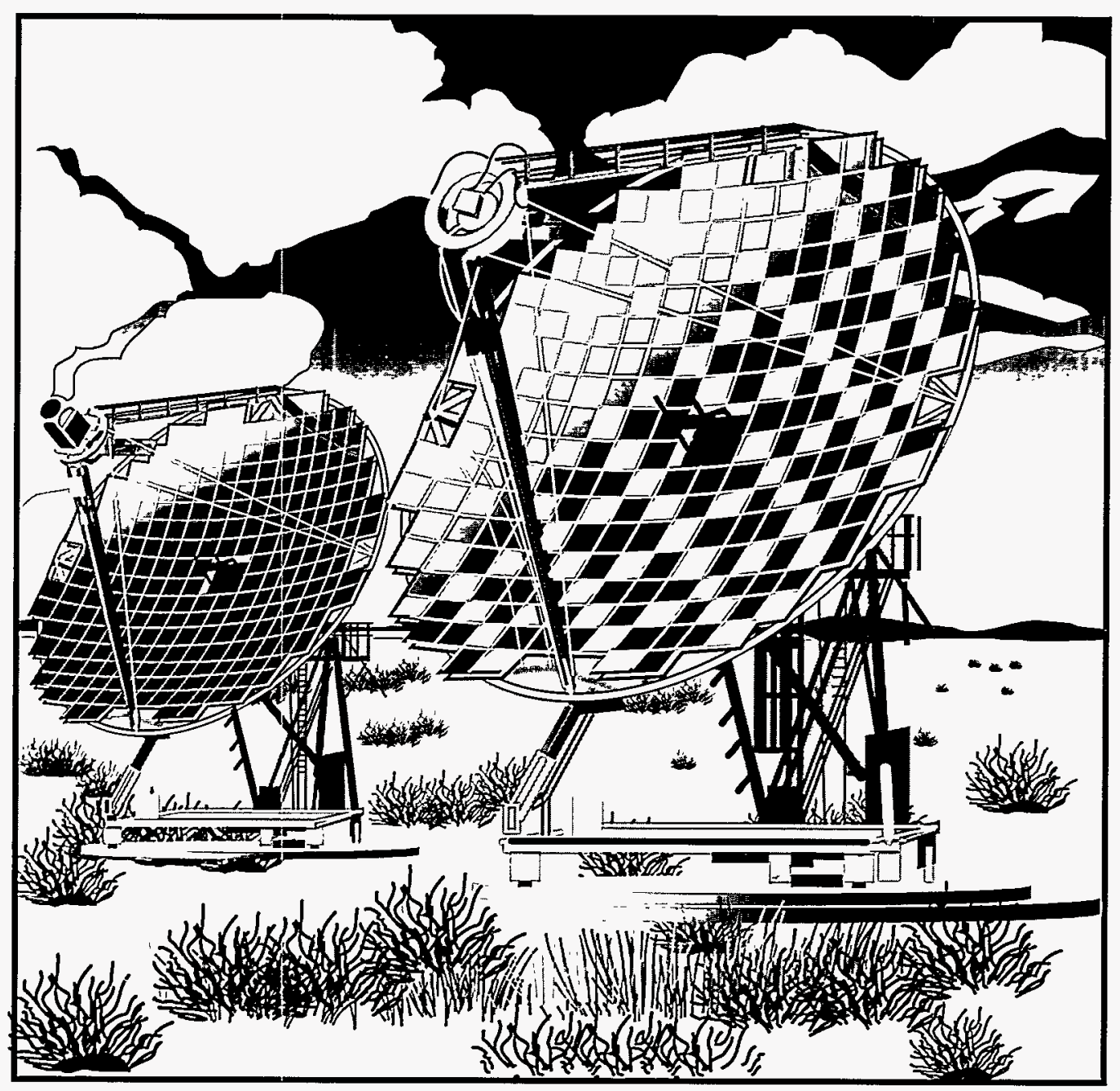

Prepared by

Sandia National Laboratories

Albuquerque, New Mexico 87185 and Livermore, California 94550 for the United States Department of Energy

under Contract DE-AC04-94AL85000 
Issued by Sandia National Laboratories, operated for the United States Department of Energy by Sandia Corporation.

NOTICE: This report was prepared as an account of work sponsored by an agency of the United States Government. Neither the United States Government nor any agency thereof, nor any of their employees, nor any of their contractors, subcontractors, or their employees, makes any warranty, express or implied, or assumes any legal liability or responsibility for the accuracy, completeness, or usefulness of any information, apparatus, product, or process disclosed, or represents that its use would not infringe privately owned rights. Reference herein to any specific commercial product, process, or service by trade name, trademark, manufacturer, or otherwise, does not necessarily constitute or imply its endorsement, recommendation, or favoring by the United States Government, any agency thereof or any of their contractors or subcontractors. The views and opinions expressed herein do not necessarily state or rellect those of the United States Government, any agency thereof or any of their contractors.

Printed in the United States of America. This report has been reproduced directly from the best available copy.

Available to DOE and DOE contractors from

Office of Scientific and Technical Information

PO Box 62

Oak Ridge, TN 37831 .

Prices available from (615) 576-8401, FTS 626-8401

Available to the public from

National Technical Information Service

US Department of Commerce

5285 Port Royal Rd

Springfield, VA 22161

NTIS price codes

Printed copy: A03

Microfiche copy: A01 


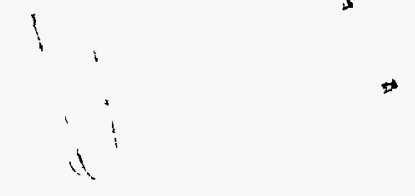

SAND94-0785

Distribution

Unlimited Release

Printed February 1995

\title{
OPTICAL PERFORMANCE OF THE TBC-2 SOLAR COLLECTOR BEFORE AND AFTER THE 1993 MIRROR LUSTERING
}

\author{
Richard Houser and John Strachan \\ Solar Thermal Test Department \\ Sandia National Laboratories \\ Albuquerque, NM 87185-6215
}

\begin{abstract}
In 1993, the mirror facets of one of Sandia's point-focusing solar collectors, the Test Bed Concentrator \#2 (TBC-2), were reconditioned. The concentrator's optical performance was evaluated before and after this operation. This report summarizes and compares the results of these tests. The tests demonstrated that the concentrator's total power and peak flux were increased while the overall flux distribution in the focal plane remained qualitatively the same.
\end{abstract}

\section{DISCLAIMER}

This report was prepared as an account of work sponsored by an agency of the United States Government. Neither the United States Government nor any agency thereof, nor any of their employees, makes any warranty, express or implied, or assumes any legal liability or responsibility for the accuracy, completeness, or usefulness of any information, apparatus, product, or process disclosed, or represents that its use would not infringe privately owned rights. Reference herein to any specific commercial product, process, or service by trade name, trademark, manufacturer, or otherwise does not necessarily constitute or imply its endorsement, recommendation, or favoring by the United States Government or any agency thereof. The views and opinions of authors expressed herein do not necessarily state or reflect those of the United States Government or any agency thereof. 


\section{DISCLAIMER}

Portions of this document may be illegible in electronic image products. Images are produced from the best available original document. 


\section{Contents}

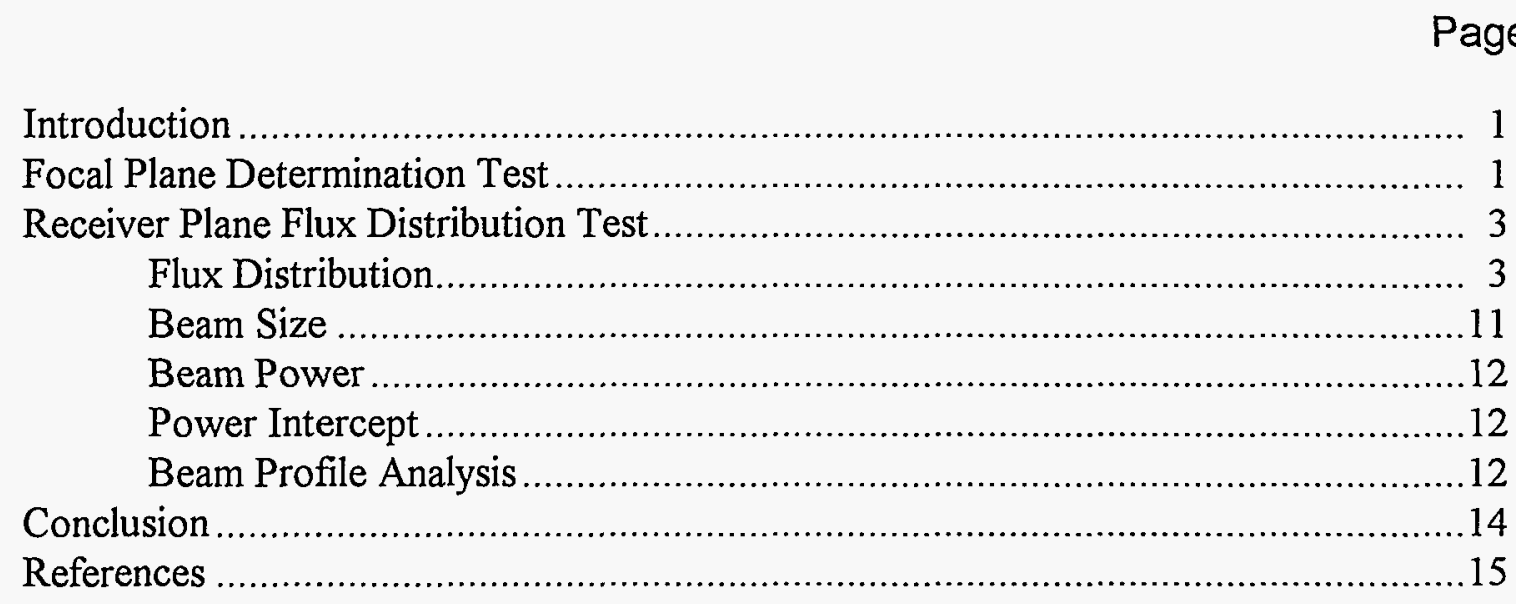

\section{Figures}

1. TBC-2 test configuration showing flux target location ................................ 1

2. Location of dish's focal plane before and after lustering process ....................... 3

3. Contour plot of TBC-2 beam at $0.51 \mathrm{~cm}(0.2 \mathrm{in}$.) behind focal plane ................. 5

4. Contour plot of TBC-2 beam at $8.1 \mathrm{~cm}$ (3.2 in.) behind focal plane................... 6

5. Contour plot of TBC-2 beam at $15.8 \mathrm{~cm}$ (6.2 in.) behind focal plane................... 7

6. Contour plot of TBC-2 beam at $23.4 \mathrm{~cm}(9.2 \mathrm{in}$.) behind focal plane.................. 8

7. Contour plot of TBC-2 beam at $31.0 \mathrm{~cm}$ (12.2 in.) behind focal plane ................ 9

8. Peak flux measurements before and after lustering process ............................. 10

9. Beam diameter before and after lustering process........................................11

10. TBC-2 power intercept curve ............................................................ 13

11. Profile plots of $\mathrm{TBC}-2$ beams before and after lustering process........................13

\section{Tables}

1. Beam Measurements in Focal Region During Focal Plane Determination Test .......................................................................... 2

2. Peak Flux and Total Power Measurements at the Focal Point.............................. 10

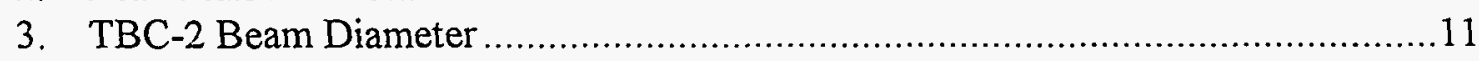

4. TBC-2 Power Measurements........................................................... 12

5. BCS Image Power Data for Power Intercept Curve ....................................14 


\section{INTRODUCTION}

In the summer and fall of 1993, the mirrored surfaces of Sandia National Laboratories' (Sandia's) Test Bed Concentrator \#2 (TBC-2) were reconditioned, or lustered. This report presents the results of the dish's optical performance before and after this lustering process. The tests described in this report were performed using Sandia's Beam Characterization System (BCS) [1,2], as well as cold water calorimetry (CWC). The BCS facilitates the measurement of the flux in the dish's focal region; it includes a diffusively reflective flux target that is positioned in the focal region, and a digital camera that is used to capture an image of the flux reflected from the target. Two flux gauges embedded in the flux target provide absolute measures of the flux density at two points on the target. The peak flux and the overall power in the beam can be obtained from the BCS as well as a flux map. For dish-type collectors the accuracy (standard deviation of expected error) of the BCS is 6 to $10 \%$.

The BCS flux target employed in the evaluation of the TBC-2 is a circular 30-inch (in.)-diameter water-cooled aluminum plate with a Lambertian aluminum-oxide surface. It was mounted to the receiver ring of the TBC-2 (the ring is indicated by the arrow in Figure 1), and positioned along the axis of the dish by a linear actuator.

The performance testing of the "prelustered" dish took place on January 20 and 21, 1993, and the postluster tests were performed on December 22, 1993, and January 3, 1994. The two-part objective of both the before and after optical evaluations was a) to determine the location of the dish's focal plane and b) to characterize the flux at the focus and in the region behind it, in the region of the receiver.

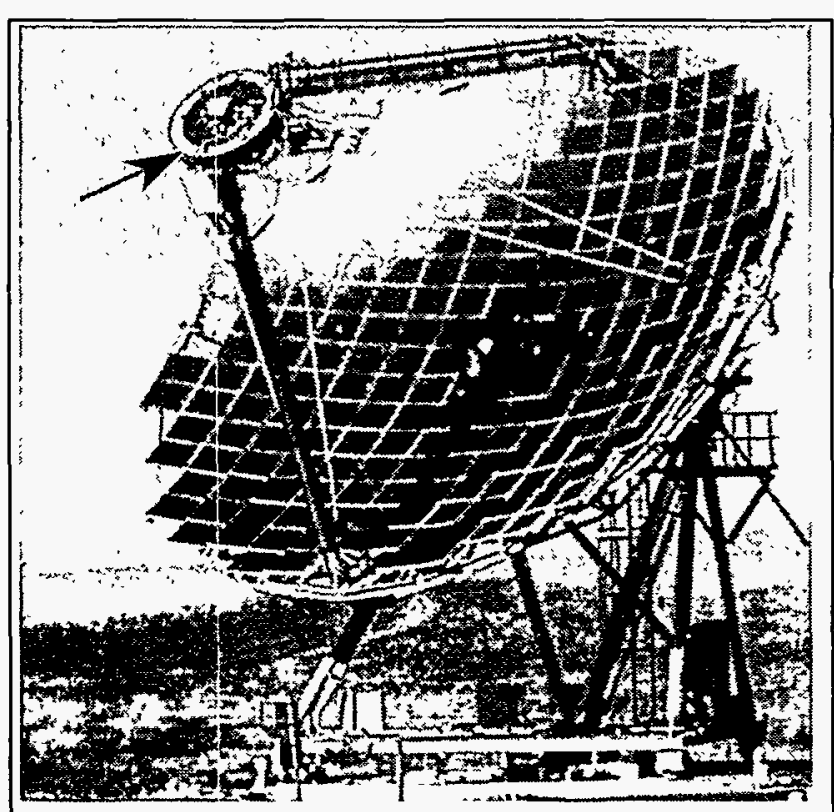

Figure 1. TBC-2 test configuration showing flux target location

\section{FOCAL PLANE DETERMINATION TEST}

For the purpose of this text a flux target is moved through the focal point while images and sensor data are acquired. These data are then reduced using a spreadsheet program to obtain the relative peak flux, relative power, and the diameter of a circle containing all flux equal to or greater than $10 \%$ of the value of the peak flux. Other than setting up the zoom, f-stop, and focus near the focal point, no corrections were made for scaling changes attributable to the change in the camera-totarget distance as the target is moved. While it is true that this introduces errors into the resulting fluxmaps, it does not prevent researchers from getting a sufficiently accurate relative measure of beam power and beam diameter at the selected positions in the focal region. 
The before-and-after focal plane location test indicates that the dish's focal plane did not change significantly and is located $71.8 \mathrm{~cm}$ (28.3 in.) toward the vertex from the dish reference plane (see Table 1 and Figure 2).

\section{Table 1. Beam Measurements in Focal Region During Focal Plane Determination Test}

\begin{tabular}{|c|c|c|c|c|c|c|c|}
\hline \hline \multicolumn{4}{|c|}{$\begin{array}{c}\text { Before Lustering } \\
\text { Day 20 (1993) at 11:45 AM }\end{array}$} & \multicolumn{3}{c|}{ After Lustering } \\
\hline \multicolumn{3}{|c|}{ Insolation: 0.895 kW/m² 356 (1993) at 11:45 AM } \\
\hline $\begin{array}{c}\text { Position } \\
\text { Relative to } \\
\text { Ref. Point } \\
\text { (cm) }\end{array}$ & $\begin{array}{c}\text { Relative } \\
\text { Power } \\
\text { (\% of Max.) }\end{array}$ & $\begin{array}{c}\text { Relative } \\
\text { Peak Flux } \\
(\% \text { of Max.) }\end{array}$ & $\begin{array}{c}\text { Beam } \\
\text { Diameter } \\
(\mathrm{cm})\end{array}$ & $\begin{array}{c}\text { Position } \\
\text { Relative to } \\
\text { Ref. Point } \\
(\mathrm{cm})\end{array}$ & $\begin{array}{c}\text { Relative } \\
\text { Power } \\
\text { (\% of Max.) }\end{array}$ & $\begin{array}{c}\text { Relative } \\
\text { Peak Flux } \\
\text { (\% of Max.) }\end{array}$ & $\begin{array}{c}\text { Beam } \\
\text { Diameter } \\
\text { (cm) }\end{array}$ \\
\hline 69.1 & 97.8 & 89.1 & 98.4 & 69.2 & 97.4 & 90.8 & 99.1 \\
\hline 69.7 & 98.5 & 94.1 & 94.3 & 69.8 & 97.5 & 94.3 & 96.4 \\
\hline 70.4 & 98.9 & 97.5 & 91.1 & 70.4 & 97.8 & 96.9 & 93.7 \\
\hline 71.1 & 99.4 & 99.2 & 88.6 & 71.0 & 99.3 & 98.7 & 91.9 \\
\hline 71.6 & 99.4 & 100.0 & 87.8 & 71.5 & 99.4 & 100.0 & 91.9 \\
\hline 72.4 & 99.7 & 99.2 & 87.8 & 72.2 & 99.6 & 99.6 & 91.9 \\
\hline 73.1 & 100.0 & 97.5 & 90.2 & 72.7 & 99.0 & 97.8 & 93.7 \\
\hline 73.6 & 99.9 & 94.1 & 93.5 & 73.0 & 99.3 & 96.5 & 94.6 \\
\hline 74.4 & 99.8 & 88.7 & 97.6 & 73.6 & 99.1 & 93.9 & 97.3 \\
\hline 75.0 & 99.3 & 84.5 & 100.0 & 73.9 & 98.7 & 91.7 & 99.1 \\
\hline 74.8 & 99.7 & 84.9 & 100.0 & 74.2 & 98.6 & 90.0 & 100.0 \\
\hline
\end{tabular}




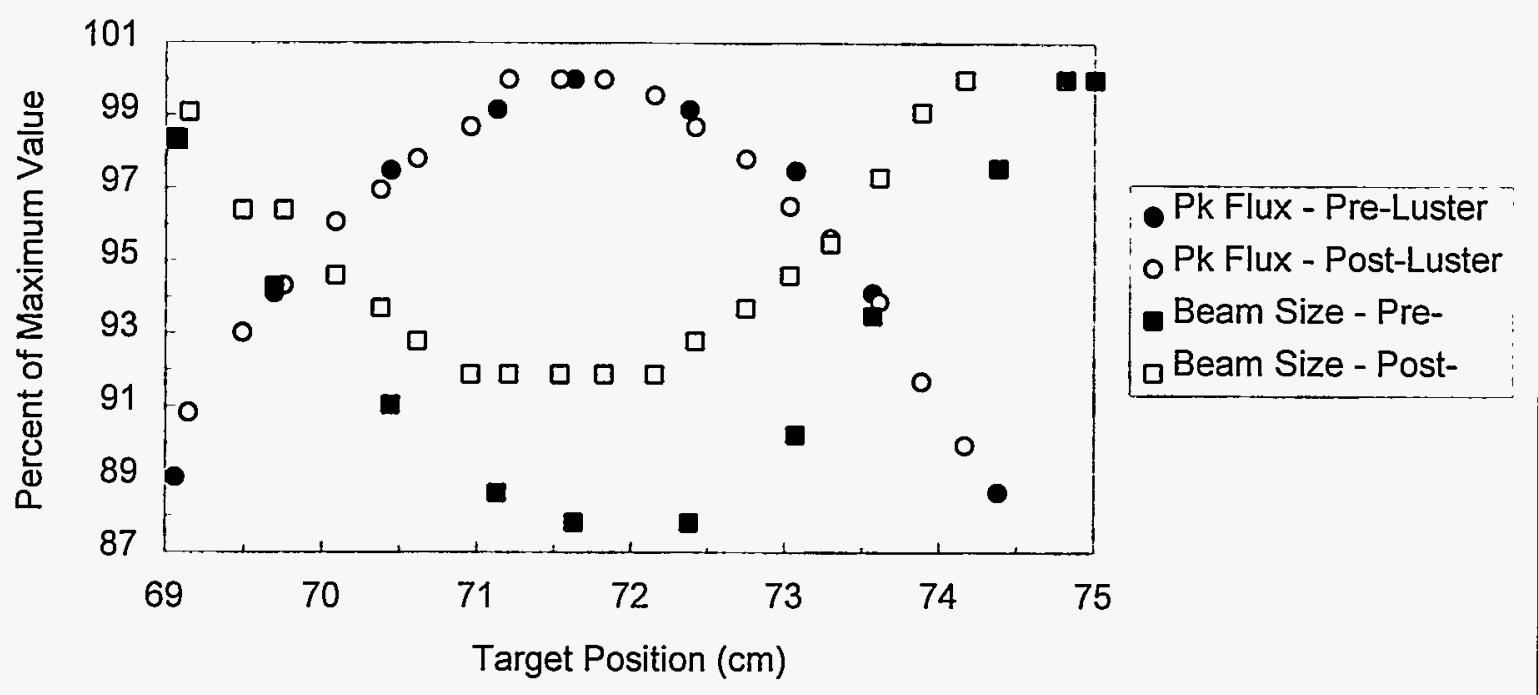

Figure 2. Location of dish's focal plane before and after lustering process

\section{RECEIVER PLANE FLUX DISTRIBUTION TEST}

\section{Flux Distribution}

Before and after the TBC-2 lustering, the dish's flux distribution at the focal plane and in the region behind it was characterized using the BCS. Flux maps were obtained at the focal plane ${ }^{1}$ and at four positions behind it: $8.1 \mathrm{~cm}(3.2$ in.), $15.7 \mathrm{~cm}$ (6.2 in.), $23.3 \mathrm{~cm}(9.2$ in.), and $30.9 \mathrm{~cm}$ (12.2 in.). Color contour plots of the flux distribution at these five locations are presented in Figures 3 through 7 .

A BCS image was acquired of the flux on the target while positioned at each focal plane location. Sensor data from the flux gauges were acquired simultaneously as was an insolation reading from a normal incidence pyroheliometer, or NIP. The target flux measurements were equated to the corresponding image intensity levels in the BCS image to obtain a measure of the peak flux. The image picture levels (pixel levels) were integrated using this peak flux value to estimate the total beam power. The effective beam diameter was obtained using the BCS's image analysis software functions. The TBC-2's peak flux, power, and beam diameter at the selected positions before and after the lustering process are presented in this report.

The flux maps indicate that qualitatively the distribution of flux in the focal region did not change as a result of the lustering process (see Figures 3 through 7). However, the peak flux that the dish is capable of producing did increase. Prior to the lustering of the TBC-2 mirrors, the

\footnotetext{
${ }^{1}$ The focal point is located $71.8 \mathrm{~cm}$ [28.3 in.] toward the vertex from the reference plane.
} 
peak flux at the focal plane was $16,598 \mathrm{~kW} / \mathrm{m}^{2}$ (Table 2); after lustering and realignment the peak flux measured $17,953 \mathrm{~kW} / \mathrm{m}^{2}$, an increase of approximately $7.5 \%$. Figure 8 shows the peak flux values before and after the lustering process as measured with the BCS and normalized to the average total power measured by CWC (pre-luster calorimetry was performed in May and June 1993 and post-luster calorimetry in November 1993). There is an unexpected drop in the 63.8$\mathrm{cm}(25.1$-in.) target position following the lustering and realignment. This lower flux level was observed on both postluster test dates (December 22, 1993 and January 3, 1994) and is unexplained at the present. 


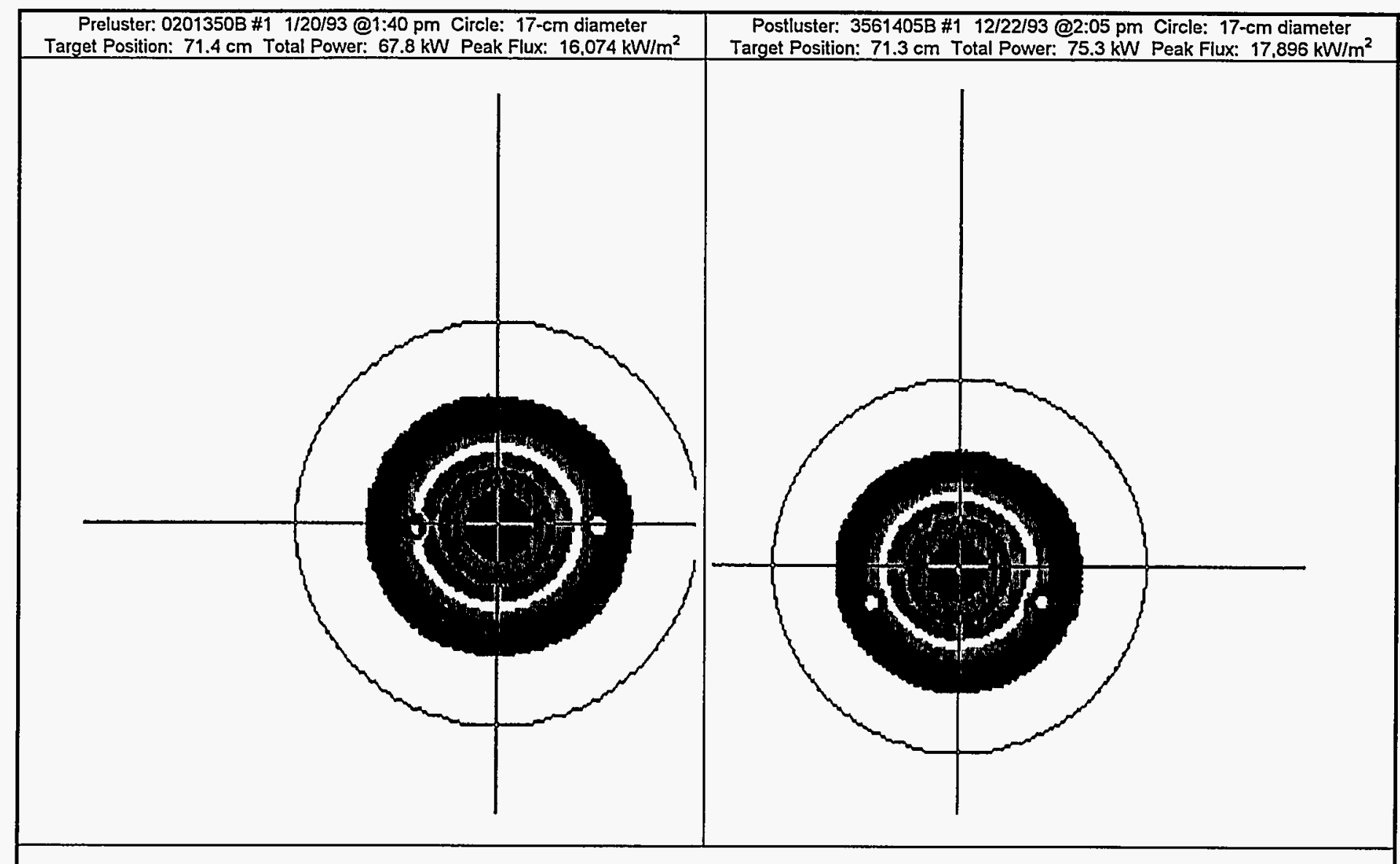

Figure 3. Contour plot of TBC-2 beam at $0.51 \mathrm{~cm}(0.2 \mathrm{in}$.) behind focal plane 


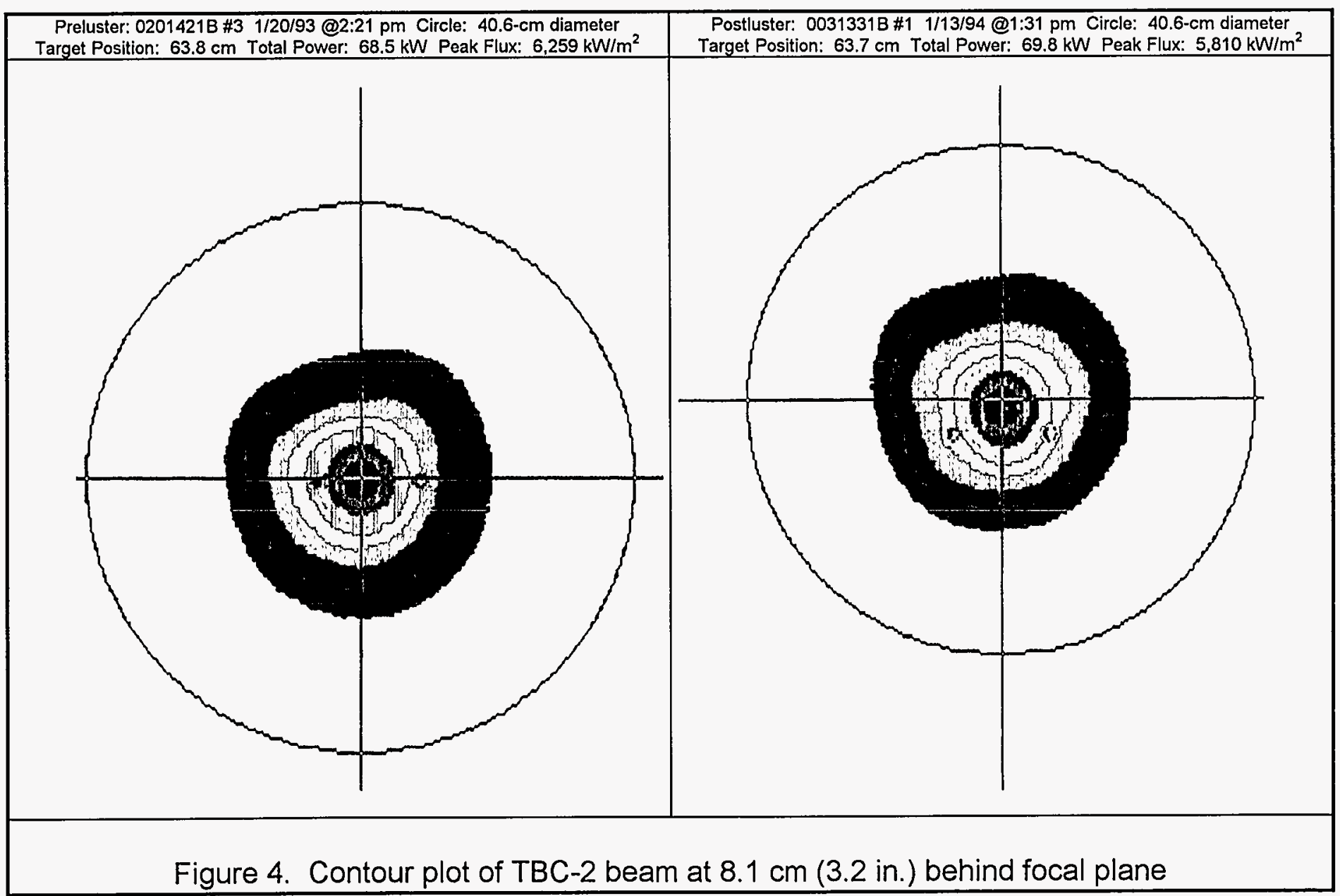




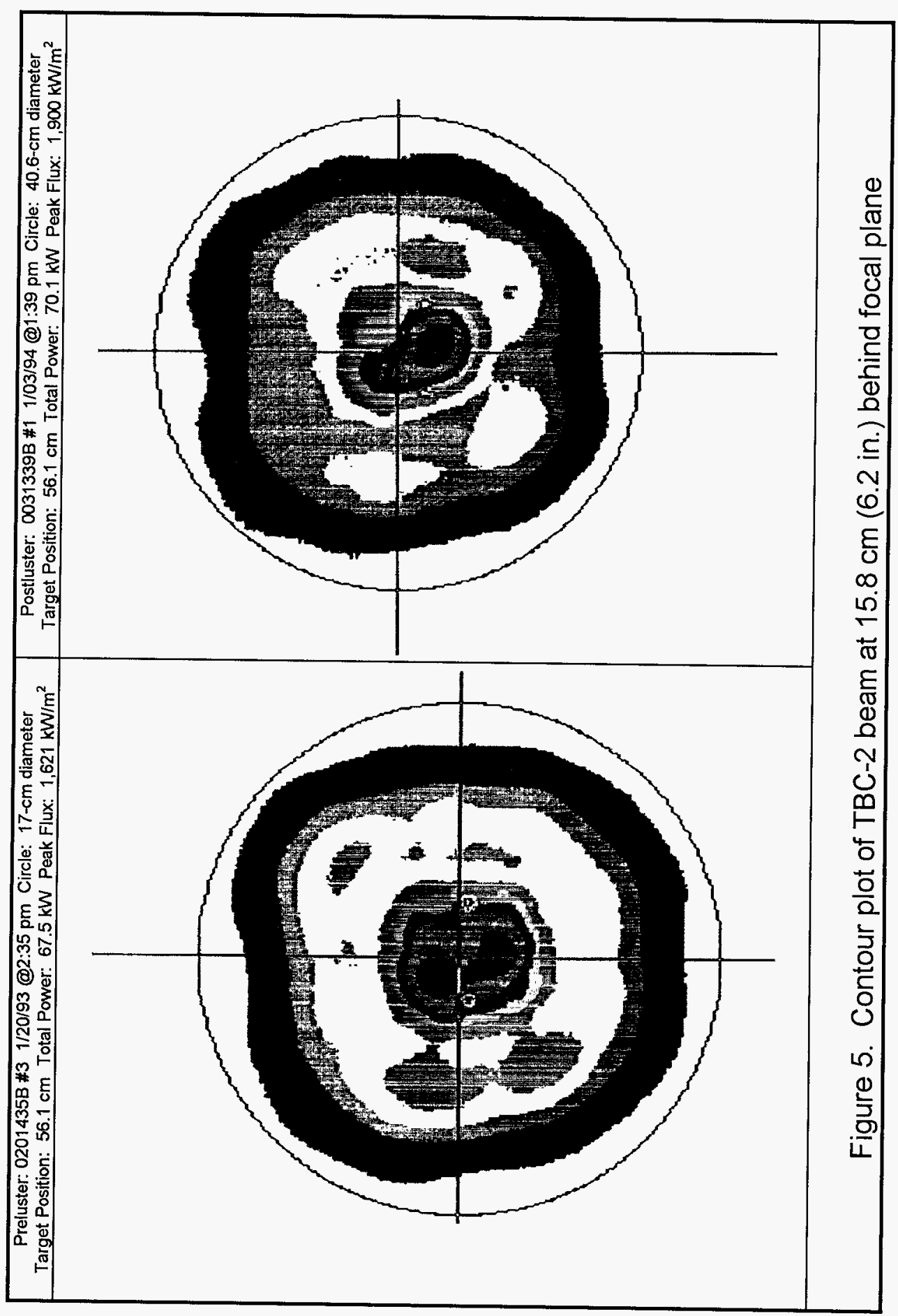




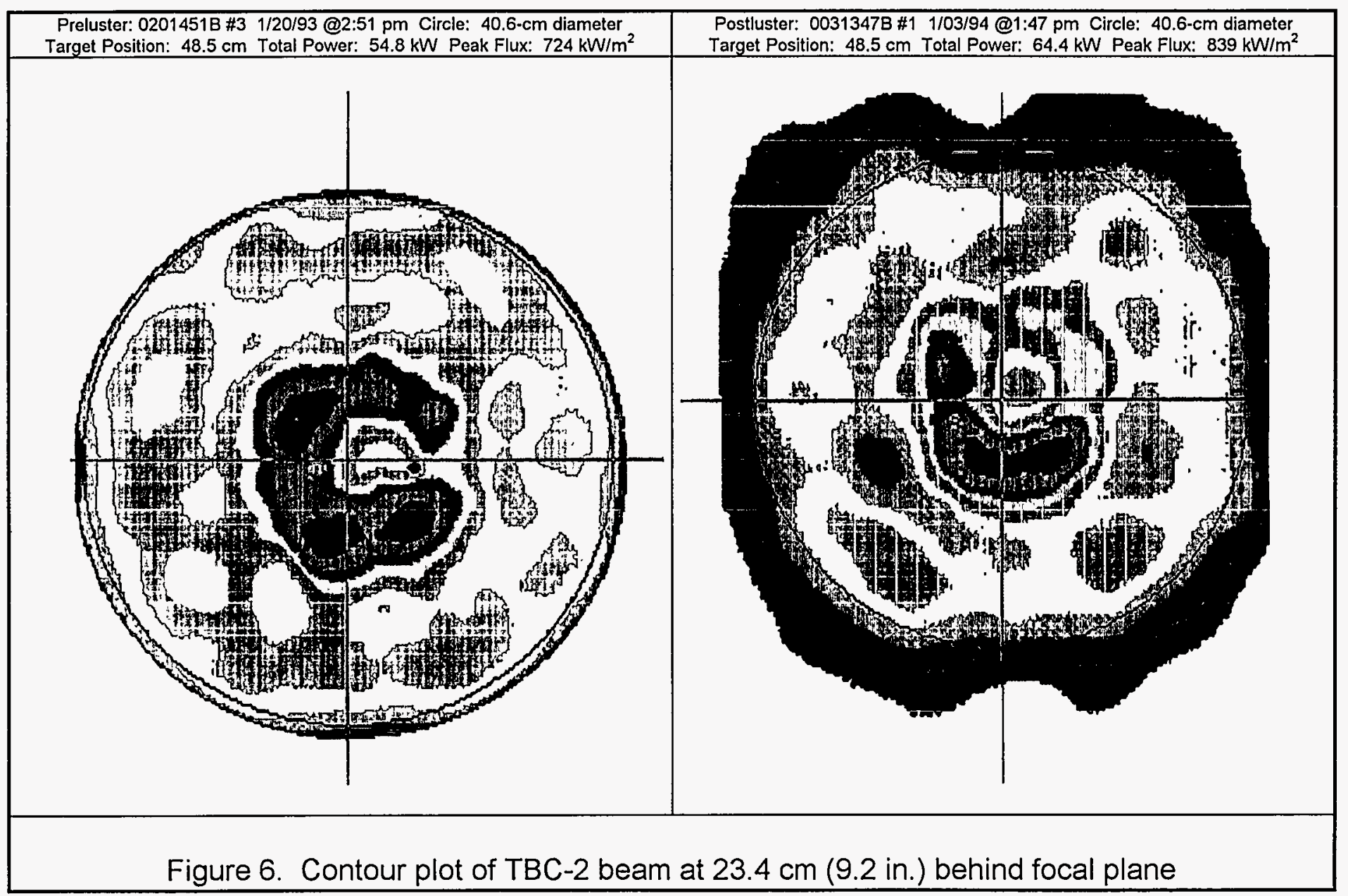




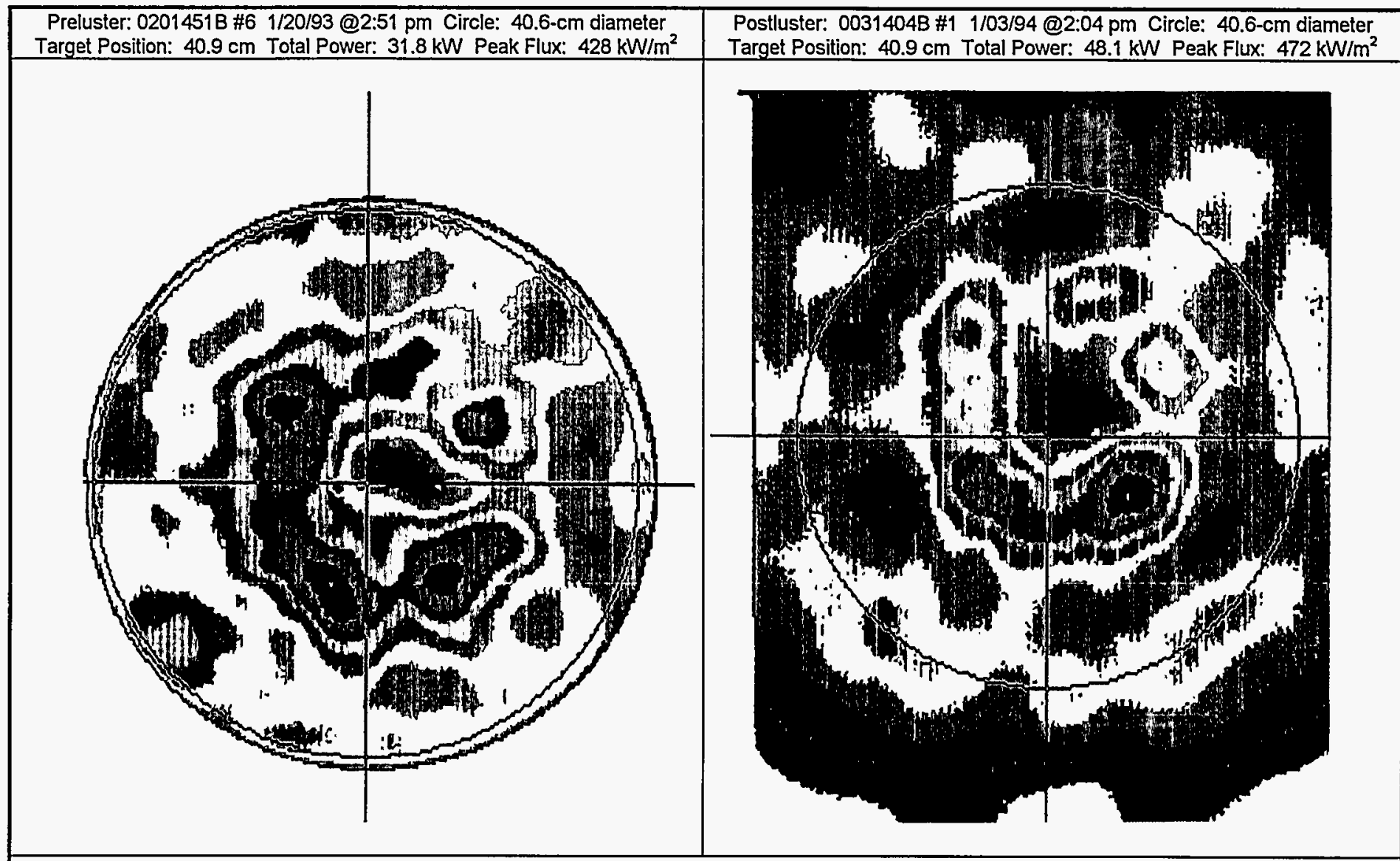

Figure 7. Contour plot of TBC-2 beam at $31.0 \mathrm{~cm}$ (12.2 in.) behind focal plane 


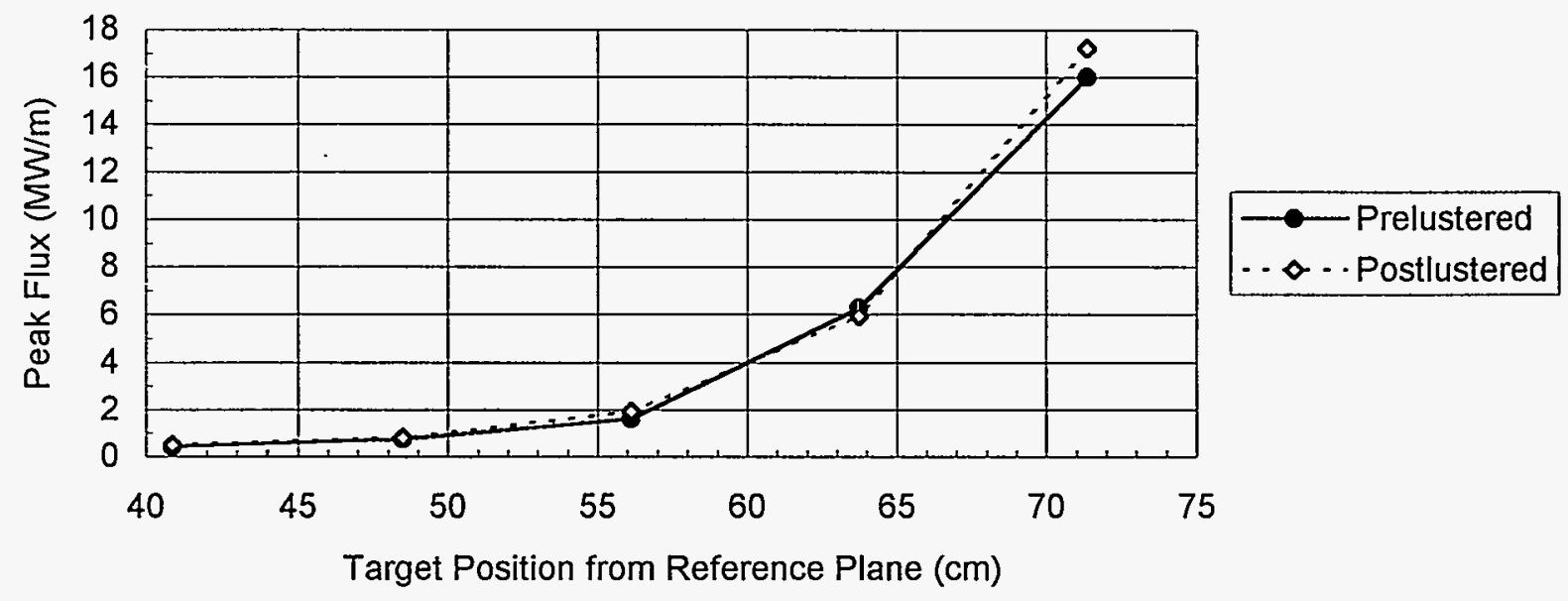

Figure 8. Peak flux measurements before and after lustering process

\begin{tabular}{|c|c|c|c|c|c|}
\hline \multicolumn{6}{|c|}{ Table 2. Peak Flux and Total Power Measurements at the Focal Point } \\
\hline $\begin{array}{l}\text { Distance } \\
\text { from } \\
\text { mounting } \\
\text { plane } \\
(\mathrm{cm})\end{array}$ & $\begin{array}{l}\text { Distance from } \\
\text { focal plane }\end{array}$ & \begin{tabular}{|c|} 
Peak flux \\
Normalized to \\
Calorimetry Power \\
(as indicated \\
below) \\
$\left(\mathrm{kW} / \mathrm{m}^{2}\right)$
\end{tabular} & $\begin{array}{c}\begin{array}{c}\% \text { Change in } \\
\text { Peak Flux after } \\
\text { Lustering }\end{array} \\
(\%)\end{array}$ & $\begin{array}{c}\text { Total Power } \\
\text { Measured } \\
\text { with BCS } \\
(\mathrm{kW})\end{array}$ & $\begin{array}{l}\text { \% Change in } \\
\text { BCS } \\
\text { Measured } \\
\text { Power after } \\
\text { Lustering } \\
(\%)\end{array}$ \\
\hline \multicolumn{2}{|c|}{$\begin{array}{l}\text { Before Lustering (data } \\
\text { file:R93020R) }\end{array}$} & $\begin{array}{c}\text { (Calorimeter Pwr: } \\
70.5 \mathrm{~kW} \text { ) }\end{array}$ & & & \\
\hline 71.4 & -0.5 & 16598 & 丩 & 68.0 & ل! \\
\hline 63.8 & -8.1 & 6442 & & 68.5 & \\
\hline 56.1 & -15.8 & 1693 & $\Downarrow$ & 67.5 & $\Downarrow$ \\
\hline 48.5 & -23.4 & 751 & & 54.8 & \\
\hline 40.9 & -31.0 & 474 & $\Downarrow$ & 31.8 & $\Downarrow$ \\
\hline \multicolumn{2}{|c|}{$\begin{array}{l}\text { After Lustering (data } \\
\text { file:R94003A) }\end{array}$} & $\begin{array}{c}\text { (Calorimeter Pwr: } \\
77.9 \mathrm{~kW} \text { ) }\end{array}$ & & & \\
\hline 71.4 & -0.5 & 17953 & 8.2 & 74.7 & 9.9 \\
\hline 63.8 & -8.1 & 6606 & 2.5 & 70.2 & 2.5 \\
\hline 56.1 & -15.8 & 2183 & 28.9 & 68.1 & 0.9 \\
\hline 48.5 & -23.4 & 900 & 19.9 & 62.1 & 13.3 \\
\hline 40.9 & -31.0 & 553 & 16.5 & 35.2 & 10.7 \\
\hline
\end{tabular}




\section{Beam Size}

The beam size at TBC-2's focal point appears to be unchanged by the lustering and realignment processes. At its focus, which tests located at $71.8 \mathrm{~cm}(28.3$ in.) from the reference plane, the measured beam diameter was $11.0 \pm 0.2 \mathrm{~cm}$ before and $10.8 \pm 0.2 \mathrm{~cm}$ after the reconditioning of the mirror facets. Beam diameter is defined as the diameter of a circle containing all flux in a beam whose intensity is $\geq 10 \%$ of that beam's peak flux intensity.

Figure 9 provides a graphical view of the preluster and postluster beam diameters measured at the five axial positions in the dish's focal region (see Table 3 for numerical values).

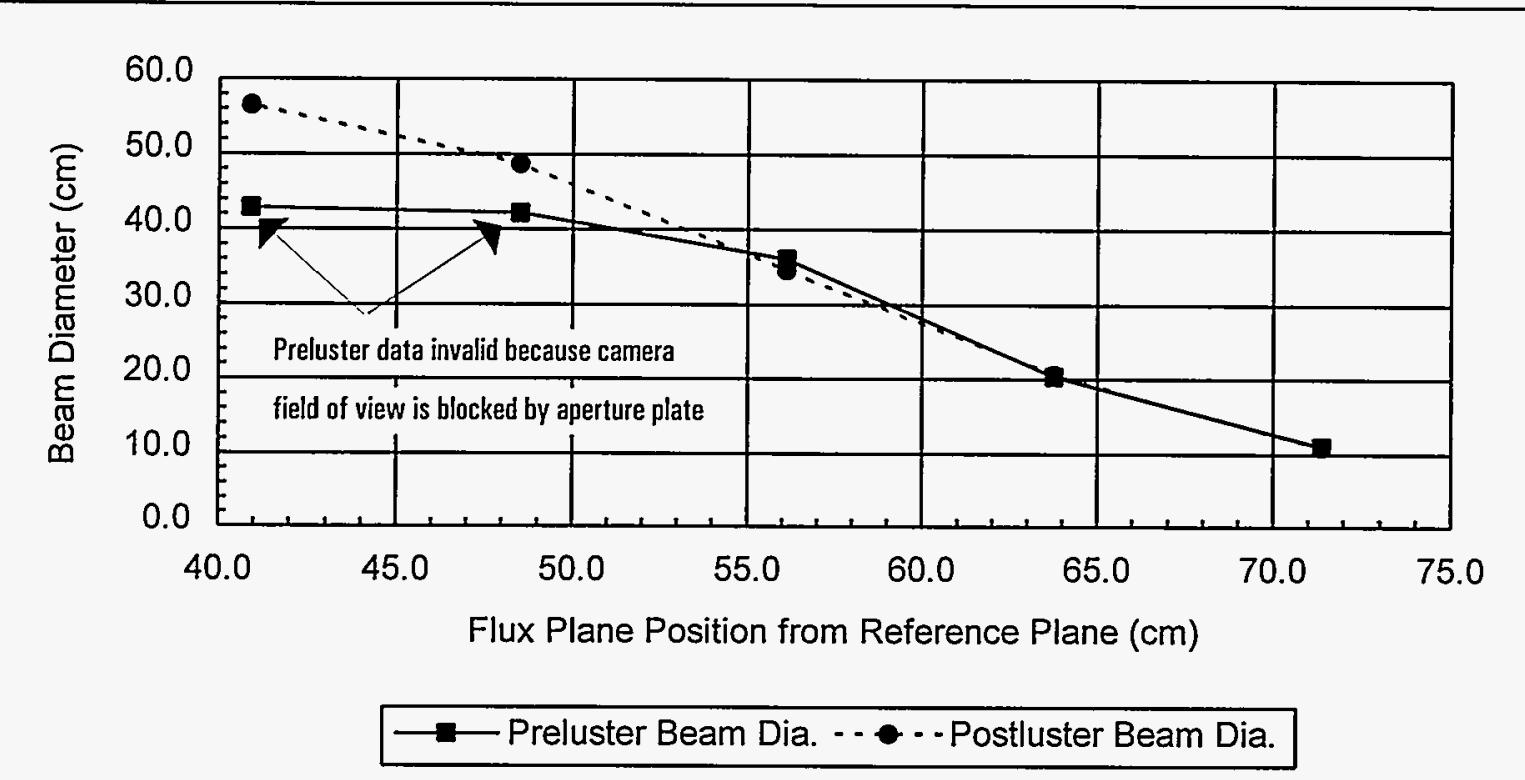

Figure 9. Beam diameter before and after lustering process

\begin{tabular}{|c|c|c|}
\hline \multicolumn{3}{|c|}{ Table 3. TBC-2 Beam Diameter } \\
\hline \hline $\begin{array}{c}\text { BCS Target } \\
\begin{array}{c}\text { Position from } \\
\text { Reference Plane } \\
(\mathrm{cm})\end{array}\end{array}$ & $\begin{array}{c}\text { Preluster Beam } \\
\text { Diameter (cm)-file: } \\
\text { R093020R.WK1 }\end{array}$ & $\begin{array}{c}\text { Postluster Beam } \\
\text { Diameter (cm)-file: } \\
\text { R093020R.WK1 }\end{array}$ \\
\hline 71.4 & 11.0 & 10.8 \\
\hline 63.8 & 20.3 & 20.6 \\
\hline 56.1 & 36.1 & 34.6 \\
\hline 48.5 & data invalid & 48.7 \\
\hline 40.9 & data invalid & 56.5 \\
\hline
\end{tabular}

In the preluster test, the beam's diameter and power measurements were not accurate in the region $22.8 \mathrm{~cm}(9 \mathrm{in}$. behind the focus (and beyond). An accurate measurement was prevented by the presence of the dish's aperture plate, which limited the BCS camera's field of view for the beam data obtained at the 22.8- and 30.4-cm (9- and 12-in.) positions behind the focus. ${ }^{2}$ For the postluster test, the aperture plate was removed.

\footnotetext{
${ }^{2}$ During the preluster beam characterization the TBC-2 was equipped as usual with its aperture plate. This is a water-cooled flux shield that is typically mounted on the vertex side of the dish's mounting ring and provides a means of shielding the receiver or dish-test subject from the dish's intense beam of
} 


\section{Beam Power}

Although excellent for characterizing collector flux distributions, the BCS is not particularly well-suited for making accurate beam power measurements. At Sandia, CWC is currently the preferred measurement, and calorimetry measurements of the TBC-2's total beam power were made in the same time frame as the preluster and postluster beam characterizations. The preluster and postluster calorimetry, performed in near-solar-noon conditions and subsequently normalized to an insolation level of $1,000 \mathrm{~W} / \mathrm{m}^{2}$, yielded total power values of $70.5 \pm 1$ and 77.9 $\pm 1 \mathrm{~kW}$, respectively. Error analysis established the measurement accuracy at $1.5 \%$. By contrast, the BCS accuracy is 6 to $10 \%$. For this reason, the beam power measurements cited here are those made by calorimetry. For comparison purposes, Table 4 lists the TBC-2 power measurements made at or close to the focal plane obtained with both the BCS and the CWC.

\begin{tabular}{|l|c|c|}
\hline \multicolumn{3}{|c|}{ Table 4. TBC-2 Power Measurements } \\
\hline \hline & $\begin{array}{c}\text { Preluster } \\
\text { Beam Power }\end{array}$ & $\begin{array}{c}\text { Postluster } \\
\text { Beam Power }\end{array}$ \\
\hline $\begin{array}{l}\text { Beam } \\
\text { Characterization } \\
\text { (71.4 cm from } \\
\text { reference plane) }\end{array}$ & $68 \pm 5 \mathrm{~kW}$ & $75 \pm 6 \mathrm{~kW}$ \\
\hline $\begin{array}{l}\text { Calorimetry } \\
\text { (72.2 cm from } \\
\text { reference plane) }\end{array}$ & $70.5 \pm 1 \mathrm{~kW}$ & $77.9 \pm 1 \mathrm{~kW}$ \\
\hline
\end{tabular}

\section{Power Intercept}

The lustering process increased the total dish power (from $70.5 \pm 1$ to $77.9 \pm 1 \mathrm{~kW}$ ). Figure 10 provides power intercept curves that were obtained at two focal plane locations (71.4 and $63.8 \mathrm{~cm}$ ( 28.1 and $25.1 \mathrm{in}$.) from the dish reference plane) before and after the mirror reconditioning. Table 5 gives the data from which the curve was drawn. The power values were obtained from the BCS images or flux maps. The absolute accuracy of these beam power values is \pm 8 to $10 \%$, but the relative accuracy (i.e., the accuracy of one power value relative to the next) is \pm 2 to $4 \%^{3}$.

\section{Beam Profile Analysis}

The overall flux distribution in the TBC-2 beam does not appear to have been altered by the mirror lustering process. As another means of exploring this property, the beam profiles (a beam profile is essentially a cross section of the beam) of the TBC-2 before and after the lustering process were examined. Figure 11 compares the beam profiles at two focal plane locations

collected solar energy. The shield consists of a fixed, large circular aperture plate having a 40-cm (16-in.) diameter hole (through which the flux may pass), and a rectangular plate that can slide across the aperture to block the flux from reaching the receiver or whatever test apparatus is mounted in the focal region. During the postluster test this aperture plate was absent. Because the aperture plate is normally positioned between the BCS target and the BCS camera, the camera's view of the target is constrained by the $40-\mathrm{cm}$ (16-in.) hole in the aperture plate. At a point around 17.7 or $20.4 \mathrm{~cm}(7 \mathrm{or} 8 \mathrm{in}$.) behind the focal point, the dish's collected solar beam becomes wider than the 40-cm (16-in.) diameter, and that flux is not in the BCS camera's view. Thus, for the 22.8- and 30.4-cm (9- and 12-in.) positions behind the focal point, the preluster test was unable to measure flux outside the $40-\mathrm{cm}(16-\mathrm{in}$.) inner circle of the flux target.

${ }^{3}$ The largest contributor to BCS measurement uncertainty is the calibration accuracy of the flux gauges. Relative power measurements (i.e., the power associated with individual picture elements in a BCS image) are obtained by image analysis without employing the flux gauges; their accuracy is unaffected by flux gauge inaccuracies. 


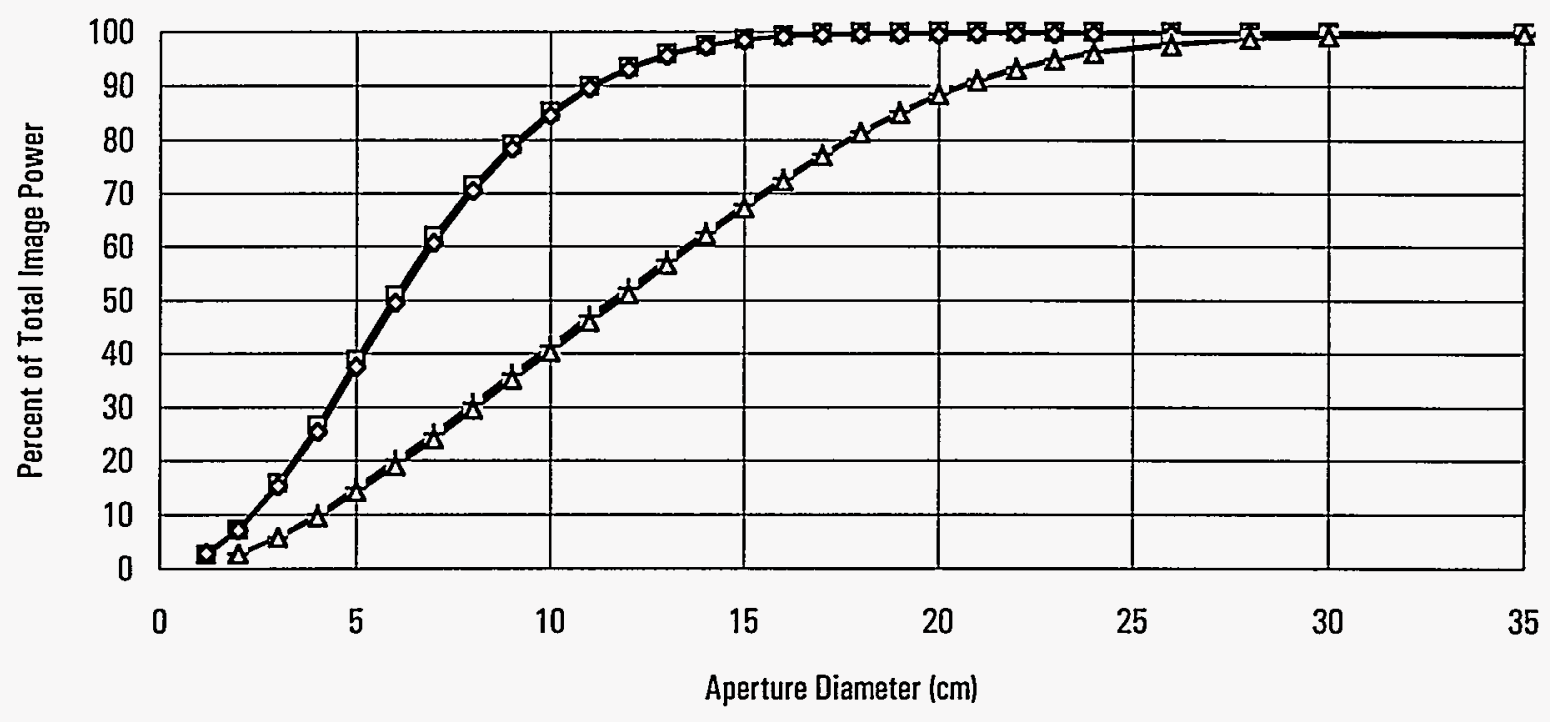

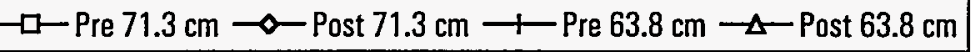

Figure 10. TBC-2 power intercept curve

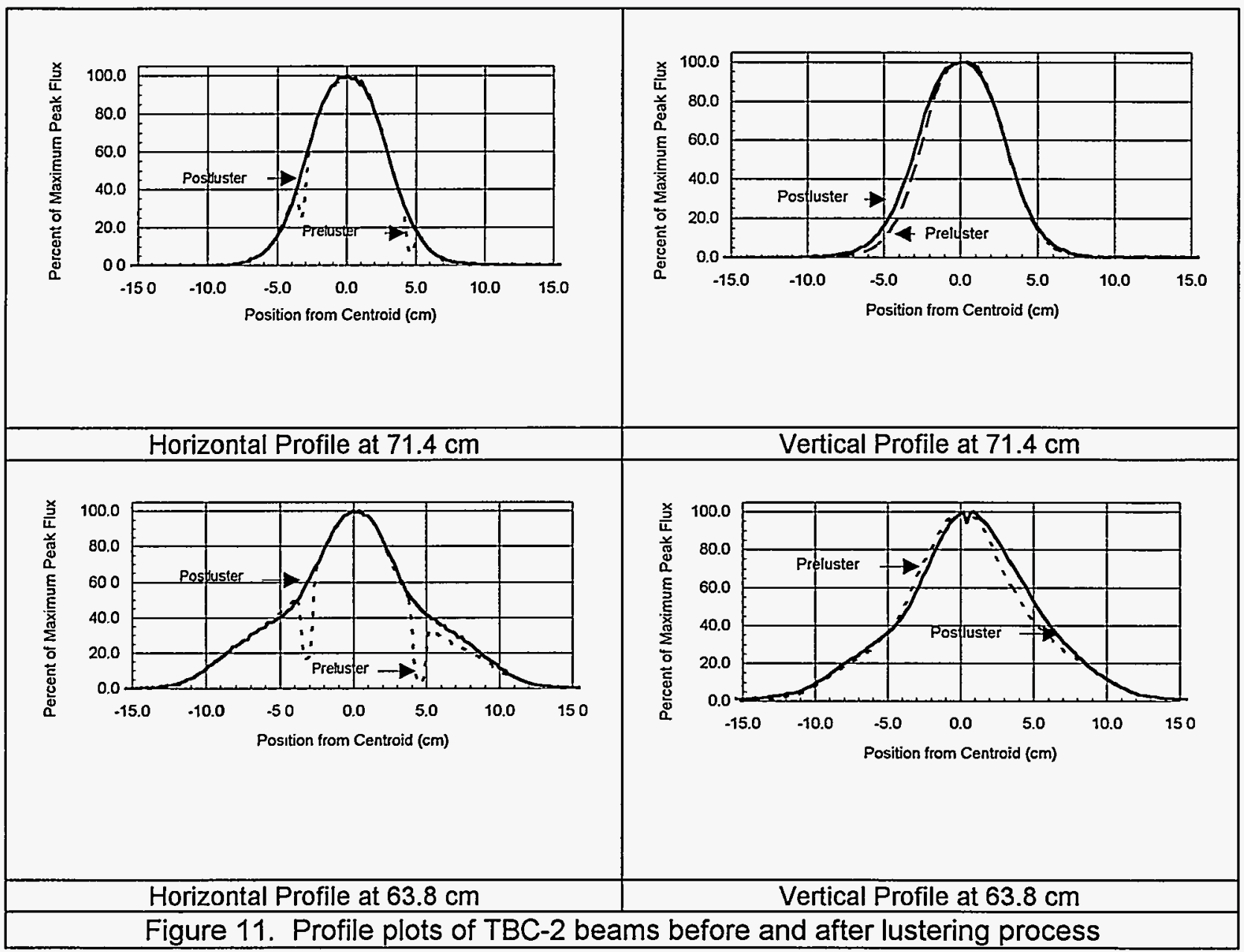




\begin{tabular}{|c|c|c|c|c|c|c|c|c|c|}
\hline \multirow{3}{*}{$\begin{array}{c}\text { Aperture } \\
\text { Diameter } \\
(\mathrm{cm})\end{array}$} & \multicolumn{4}{|c|}{ Average Power (\%) } & & \multicolumn{4}{|c|}{ Average Power (\%) } \\
\hline & \multicolumn{2}{|c|}{$\begin{array}{c}71.4 \mathrm{~cm} \text { from } \\
\text { Reference Plane }\end{array}$} & \multicolumn{2}{|c|}{$\begin{array}{c}63.8 \mathrm{~cm} \text { from } \\
\text { Reference Plane }\end{array}$} & \multirow{2}{*}{$\begin{array}{c}\text { Aperture } \\
\text { Diameter } \\
(\mathrm{cm})\end{array}$} & \multicolumn{2}{|c|}{$\begin{array}{c}71.4 \mathrm{~cm} \text { from } \\
\text { Reference Plane }\end{array}$} & \multicolumn{2}{|c|}{$\begin{array}{c}63.8 \mathrm{~cm} \text { from } \\
\text { Reference Plane }\end{array}$} \\
\hline & Before & After & Before & After & & Before & After & Before & After \\
\hline 1.20 & 2.6 & 2.8 & & & 16.00 & 99.3 & 99.0 & 72.6 & 72.2 \\
\hline 2.00 & 7.2 & 7.2 & 2.7 & 2.7 & 17.00 & 99.7 & 99.4 & 77.2 & 77.0 \\
\hline 3.00 & 15.8 & 15.3 & 5.7 & 5.7 & 18.00 & 99.8 & 99.5 & 81.4 & 81.2 \\
\hline 4.00 & 26.5 & 25.4 & 9.9 & 9.5 & 19.00 & 99.9 & 99.6 & 85.2 & 84.9 \\
\hline 5.00 & 38.7 & 37.5 & 14.8 & 14.2 & 20.00 & 100.0 & 99.6 & 88.4 & 88.3 \\
\hline 6.00 & 50.9 & 49.4 & 20.0 & 19.0 & 21.00 & 100.0 & 99.7 & 91.1 & 90.9 \\
\hline 7.00 & 61.9 & 60.6 & 25.0 & 24.0 & 22.00 & 100.0 & 99.7 & 93.3 & 93.1 \\
\hline 8.00 & 71.4 & 70.5 & 30.7 & 29.6 & 23.00 & 100.0 & 99.7 & 95.0 & 94.9 \\
\hline 9.00 & 79.1 & 78.3 & 36.0 & 35.1 & 24.00 & 100.0 & 99.7 & 96.3 & 96.1 \\
\hline 10.00 & 85.1 & 84.5 & 41.3 & 40.1 & 26.00 & 100.0 & 99.8 & 98.0 & 97.5 \\
\hline 11.00 & 89.9 & 89.5 & 46.9 & 45.8 & 28.00 & 100.0 & 99.8 & 98.8 & 98.8 \\
\hline 12.00 & 93.3 & 93.0 & 52.1 & 51.1 & 30.00 & 100.0 & 99.8 & 99.2 & 99.3 \\
\hline 13.00 & 95.9 & 95.5 & 57.4 & 56.5 & 35.00 & 100.0 & 99.8 & 99.5 & 99.7 \\
\hline 14.00 & 97.5 & 97.3 & 62.5 & 62.1 & 40.00 & 100.0 & 99.8 & 99.6 & 99.8 \\
\hline 15.00 & 98.7 & 98.4 & 67.8 & 67.2 & & & & & \\
\hline
\end{tabular}

before and after the mirror improvement process. No significant change in the TBC-2 beam is apparent.

\section{CONCLUSION}

The optical tests performed indicate that as a result of the mirror reconditioning and realignment process the location of the TBC-2's focal point did not change, but the dish's total power and peak flux capabilities did increase. The relative distribution of the flux in the collected beam appeared to remain qualitatively the same. The experimentally determined location of the dish's focal point remained at $71.8 \mathrm{~cm}$ (28.3 in.) toward the dish's vertex measured from the dish's receiver mounting plane. The normalized, overall power of the dish increased from $70.5 \mathrm{~kW}$ to $77.9 \mathrm{~kW}( \pm 1.1 \mathrm{~kW})$, a change of $10.5 \%$. The peak flux in the beam, measured at the focal point, increased from $16,598 \mathrm{~kW} / \mathrm{m}^{2}$ to $17,953 \mathrm{~kW} / \mathrm{m}^{2}( \pm 1,400 \mathrm{~kW})$, a change of $8.2 \%$. The diameter of the flux beam at the focal plane of the dish may have decreased slightly from $11.0 \mathrm{~cm}( \pm .2$ $\mathrm{cm})$ to $10.8 \mathrm{~cm}( \pm .2 \mathrm{~cm})$. The relative flux distribution in the concentrated beam remained qualitatively unchanged. 


\section{REFERENCES}

1. Strachan, J.W., 1992. Testing and Evaluation of Large-Area Heliostats for Solar Thermal Application. SAND92-1381. Sandia National Laboratories, Albuquerque, NM.

2. Strachan, J.W., 1993. "Revisiting the BCS, a Measurement System for Characterizing the Optics of Solar Collectors." SAND92-2789C. Proceedings of the 39th International Symposium of the Instrument Society of America, Albuquerque, NM. 
UNLIMITED RELEASE

INITIAL DISTRUBUTION

3M Corporation

Construction Markets Department

R. Dahlen

3M Center Bldg. 207-1 W-08

St. Paul, MN 55144-1000

3M Corporation

Solar Optics Program

P. Jaster

Bldg. 255-2N-06-3M Center

St. Paul, MN 55144-1000

Acurex Corporation

J. Schaeffer

555 Clyde Ave.

Mountain View, CA 94039

Advanced Thermal Systems

D. Gorman

7600 E. Arapahoe Rd., Ste. 215

Englewood, CO 80112

Alabama Solar Energy Center

L. Adcock

University of Alabama at Huntsville

Huntsville, AL 35899

Arizona Solar Energy Office

Department of Commerce

F. Mancini

3800 N. Central, Ste. 1200

Phoenix, AZ 85012

Arizona Public Service Company (2)

Thomas C. Lepley

P. Johnston

P.O. Box 53999

Phoenix, AZ 85072-3999

Arizona Public Service Company

Peter E. Eckert

1500 E. University

Tempe, AZ 85281
AT\&T

Tom Maurer

P.O. Box 13369

Phoenix, AZ 85002

Battelle Pacific Northwest Laboratory

D. Brown

P.O. Box 999

Richland, WA 99352

California Energy Commission

Alec Jenkins

1516 Ninth St.

MS-43

Sacramento, CA 95814-5512

California Polytechnic State University (4)

William B. Stine

Department of Mechanical Engineering

3801 West Temple Ave.

Pomona, CA 91768-4062

Central and Southwest Services (2)

E. Gastineau

J. Schroeter

MS-7RES

1616 Woodall Rogers Freeway

Dallas, TX 75202

Clarkson University

E. Thatcher

Dept. of Mechanical and Aeronautical Engineering

Potsdam, NY 13699-5725

Clever Fellows Innovation Consortium, Inc.

J.A. Corey

R.D. 1, Box 410, River Rd.

Melrose, NY 12121

Cummins Power Generation

R. Kubo

Mail Code 60125

P.O. Box 3005

Columbus, IN 47202-3005 
Cummins Power Generation South

Monte McGlaun

150 Tannehill Dr.

Abilene, TX 79602

Detroit Diesel Corporation (2)

P. Perdue

13400 Outer Drive West

Detroit, MI 48239-4001

Dynatherm Corporation

D. Wolf

1 Beaver Ct.

P.O. Box 398

Cockeyville, MD 21030

Electric Power Research Institute

J. Schaeffer

P.O. Box 10412

3412 Hillview Ave.

Palo Alto, CA 94303

Karl Thomas Feldman, Jr., Ph.D., P.E. Mechanical Engineering Consultant 1704 Stanford Dr. NE

Albuquerque, NM 87106

Florida Solar Energy Center Library 300 State Rd., Ste. 401

Cape Canaveral, FL 32920-4099

Georgia Power Company

R. Kist

333 Piedmont Ave.

Atlanta, GA 30308

Hydrogen Engineering Associates (2)

H. Braun

4421 East Osborn

Phoenix, AZ 85018
Institute of Gas Technology

Library

34245 State St.

Chicago, IL 60616

Jet Propulsion Laboratory

M. Alper

4800 Oak Grove Dr.

Pasadena, CA 91109

Los Alamos National Laboratory

M. Merrigan

MS-E13

Los Alamos, NM 87545

McDonnell-Douglas Astronautics Company (3)

R.L. Gervais

J. Rogan

D. Steinmeyer

5301 Bolsa Ave.

Huntington Beach, CA 92647

Mechanical Technology, Inc. (2)

G. Dochat

J. Wagner

968 Albany Shaker Rd.

Latham, NY 12110

NASA/Lewis Research Center

R. Shaltens

21000 Brookpark Rd.

Cleveland, $\mathrm{OH} 44135$

National Renewable Energy Laboratory (6)

M. Bohn

Gary Jorgensen

A. Lewandowski

L.M. Murphy

Tom Wendelin

Tom Williams

1617 Cole Blvd.

Golden, CO 80401-3393 
Nevada Power Company

Eric Dominguez

P.O. Box 230

Las Vegas, NV 89151

New Mexico Solar Energy Institute

G. Mulholland

New Mexico State University

Box 3 SOL

Las Cruces, NM 88003

Northern Research \& Engineering Corp.

James B. Kesseli

39 Olympia Ave.

Woburn, MA 01801-2073

Plains Electric Generation and Transmission

Cooperative, Inc.

D. Bailet

P.O. Box 6551

Albuquerque, NM 87197

Power Kinetics, Inc.

W.E. Rogers

415 River St.

Troy, NY 12180-2822

Research International

E. Saaski

18706 142nd Ave. NE

Woodinville, WA 98072

Rockwell International (2)

William Bigelow

R. LeChevalier

Energy Technology Engineering Ctr.

P.O. Box 1449

Canoga Park, CA 91304

Sacramento Municipal Utility District

Generation Systems Planning

Power Sy stems Department

Don Osborne

6201 'S' Street

Sacramento, CA 95852-1830
Salt River Project (2)

Research and Development

B. Hoffman

D. Osborn

P.O. Box 52025

Phoenix, AZ 85072-2025

SCAQMD (4)

R.S. George

J. Lents

A. Lloyd

L. Watkins

21865 Copley Dr.

Diamond Bar, CA 91765

Science Applications International Corp.

Kelly Beninga

10343 Roselle Street, Ste. G

San Diego, CA 92121

Science Applications International Corp.

B. Butler

Mail Stop 32

10260 Campus Point Ct.

San Diego, CA 92121

Solar Energy Industries Association

Ken Sheinkopf

777 N. Capitol St. NE, Ste. 805

Washington, DC 20002-4226

Solar Energy Industries Association

Scott Sklar

777 N. Capitol St. NE, Ste. 805

Washington, DC 20002-4226

Solar Kinetics, Inc. (2)

J.A. Hutchison

P. Schertz

P.O. Box 540636

Dallas, TX 75354-0636 
Solar Reactor Technologies

Robin Parker

P.O. Box 330975

Miami, FL 33233

Southern California Edison Company (3)

Mark Skowronski

C. Lopez

J. Reeves

P.O. Box 800

Walnut Grove Ave.

Rosemead, CA 91770

Stirling Machine World

B. Ross

1823 Hummingbird Ct.

West Richland, WA $99352-9542$

Stirling Technology Company (2)

M.A. White

2952 George Washington Way

Richland, WA 99352

Stirling Thermal Motors

L. Johansson

275 Metty Drive

Ann Arbor, MI 48103

Ken Stone

6882 Via Angelina

Huntington Beach, CA 92649

Sunpower, Inc. (2)

W. Beale

6 Byard St.

Athens, $\mathrm{OH} 45701$

Tech Reps, Inc.

J. Stikar

5000 Marble NE, Ste. 222

Albuquerque, NM 87110
Thermacore, Inc. (2)

D. Ernst (4)

P. Dussinger

780 Eden Rd.

Lancaster, PA 17601

University of Chicago

J. O'Gallagher

Enrico Fermi Institute

5640 Ellis Ave.

Chicago, IL 60637

University of Houston

James Richardson

Solar Energy Laboratory

4800 Calhoun

Houston, TX 77704

University of Minnesota

E.A. Fletcher

111 Church St. SE

Department of Mechanical Engineering

Minneapolis, MN 55455

University of Nevada at Las Vegas

Mechanical Engineering Department

Bob Boehm

4505 Maryland Parkway

Las Vegas, NV 89154-4026

U.S. Department of Energy

R. Annan

Code EE-13

Forrestal Building

1000 Independence Ave. SW

Washington, DC 20585

U.S. Department of Energy (6)

Gary Burch (4)

Sig Gronich (2)

Code EE-132

Forrestal Building

1000 Independence Ave. SW

Washington, DC 20585 
U.S. Department of Energy

Federal Energy Management Activities

Mark Ginsberg

EE-44

1000 Independence Ave., SW

Washington, DC 20585

\section{U.S. Department of Energy}

R. Hughey

San Francisco Operations Office

1333 Broadway

Oakland, CA 94612

U.S. Department of Energy

N. Lackey \& G. Tennyson

Albuquerque Operations Office

P.O. Box 5400

Albuquerque, NM 87115

U.S. Department of Energy

Golden Field Office

Robert Martin

1617 Cole Blvd.

Golden, CO 80401

W.G. Associates

Vern Goldberg

6607 Stonebrook Cir.

Dallas, TX 75240
Energy Research Centre

K. Inall

R.S. Phy. Sc.

Autralian National University

Canberra ACT 2601, AUSTRALIA

David Hagen

134 Kitchener St.

Garran, ACT 2605, AUSTRALIA

DLR (2)

R. Buck

Reiner Köhne

Pfaffenwaldring 38 - 40

7000 Stuttgart 80 GERMANY

DLR - Cologne (3)

MD-ET

Linder-Höhne

M. Becker

M. Boehmer

P.O. Box 906058

D-51140 Cologne GERMANY

Schlaich, Bergermann \& Partner (2)

W. Schiel

Hohenzollernstr. 1

D-7000 Stuttgart 1, GERMANY 


\section{Internal Distribution:}

$\begin{array}{rlll}\text { MS0129 } & \text { J. A. Leonard, } 12611 & 0749 & \text { A. P. Sylwester, 6203 } \\ 0129 & \text { Lori Parrott, } 12610 & 0752 & \text { T. C. Bickel, 6213 } \\ 0444 & \text { N. J. Magnani, } 5405 & 0752 & \text { M. L. Whipple, 6219 } \\ 0703 & \text { C. E. Andraka, 6216 (2) } & 0753 & \text { G. J. Jones, 6202 } \\ 0703 & \text { R. B. Diver, 6216 (6) } & 0753 & \text { C. P. Cameron, 6218 } \\ 0703 & \text { J. M. Chavez, 6215 } & 1127 & \text { Library, 6215 (3) } \\ 0703 & \text { G. J. Kolb, 6216 } & 1127 & \text { R. M. Houser, 6215 (6) } \\ 0703 & \text { T. R. Mancini, 6216 } & 0753 & \text { M. E. Ralph, 6218 } \\ 0703 & \text { D. F. Menicucci, 6216 } & 1127 & \text { P. G. Cordeiro, 6215 } \\ 0703 & \text { J. E. Pacheco, 6216 } & 1127 & \text { K. S. Rawlinson, 6215 } \\ 0703 & \text { J.W. Grossman, 6216 } & 1127 & \text { J. W. Strachan, 6215 (4) } \\ 0703 & \text { H. E. Reilly, 6216 } & 9014 & \text { S. Faas, 5371 } \\ 0703 & \text { C. E. Tyner, 6216 } & 9015 & \text { A. Baker, 5908 } \\ 0704 & \text { P. C. Klimas, 6201 } & 0899 & \text { Technical Library, 13412 (5) } \\ 0708 & \text { H. M. Dodd, 6214 } & 0619 & \text { Technical Publications, 12613 } \\ 0709 & \text { H. P. Stephens, 6212 } & 1119 & \text { Document Processing } \\ 0735 & \text { D. J. Alpert, 6200 } & & \text { for DOE/OSTI, 7613-2 (2) } \\ 0735 & \text { D. E. Arvizu, 6200 } & 9018 & \text { Central Technical Files, 8523-2 }\end{array}$

